
Bespredel and Profitable Partner

Author: Tatiana Kyselova

Source: Kyiv-Mohyla Law and Politics Journal 1 (2015): 83-112

Published by: National University of Kyiv-Mohyla Academy

http://kmlpj.ukma.edu.ua/ 


\title{
The Role of State in Ukrainian Business: Violent Bespredel and Profitable Partner ${ }^{1}$
}

\author{
Tatiana Kyselova \\ University of Turin, \\ Law Department
}

\begin{abstract}
This article analyses the role played by the Ukrainian state in the everyday business of average Ukrainian firmsin 2007-2011. Relying on the empirical findings of a five-yearcase study conducted in Eastern Ukraine, this article confirms the image of the Ukrainian state as a "grabbing hand" or bespredel - an unrestricted and violent power. The contractual relations of the researched firms and the state actors were fraught with illegal practices such as kickbacks from suppliers and the need to systematically violate the law on state procurement; pervasive Soviet-style personal relations; the risk of experiencing violent administrative pressure including criminal prosecution; and deficiencies in the enforcement of contracts. Notwithstanding these risks, the researched businesses revealed no absolute moral prohibition against joining the "grabbing hand" of the state to exploit public resources and advance their own private gains.
\end{abstract}

Key Words: state, business, contractual relations, post-Soviet transition, Ukraine.

\section{讨}

\section{Introduction}

Corruption, state extortions and undue pressure on businesses under the Yanukovych regime was one of the driving forces behind the Euromaidan Revolution in Ukraine in January 2014. These events marked Ukraine's third attempt at a transition towards a democratic society. However, every new transition is more problematic due to the heavy legacies of the previous transitional periods. ${ }^{2}$ Whether this latest attempt changes anything in the area of businessstate relations depends upon whether the role of the state in this relationship is transformed

$1 \quad$ Publication of this paper became possible due to the funding from the European Union's Horizon 2020 research and innovation program under the Marie Skłodowska-Curie grant agreement No. 6o9402-2020 researchers: Train to Move (T2M). The author thanks Dr. Chaisty, Dr. Decker, Prof. Hendley, and Dr. Kurkchiyan, for their valuable comments for earlier versions of this article. All translations in this work are by the present author unless otherwise indicated. All transliterations are from Russian language, which is spoken in Eastern Ukraine.

2 Paul Kubicek, "Problems of Post-Post-Communism: Ukraine after the Orange Revolution," Democratization 16.2 (2009): 323 . 
from "a grabbing hand" to "a helping hand." ${ }^{3}$ This research suggests that this task is neither easy nor straightforward, as the Ukrainian state was perceived to be a "grabbing hand" even under the more pro-democratic government of Yushchenko. At the same time, small and medium businesses, despite their dislike of the "grabbing hand," were ready to cooperate with it and exploit state resources to their advantage.

To advance this conclusion, this article analyses the role played by the Ukrainian state in the everyday business of average Ukrainian firms in 2007-2009 under the Yushchenko government and in 2010-2011 under the Yanukovych government. The study relies on a broadly conceived socio-legal research approach ${ }^{4}$ that places the research object within a wider societal context, analyses it through the eyes of the people involved in relations and relies on empirical research methodology. ${ }^{5}$ This article is an outcome of a larger $\mathrm{PhD}$ research project that studied

3 Andrei Shleifer and Robert Vishny, The Grabbing Hand: Government Pathologies and Their Cures (Cambridge, MA: Harvard University Press, 1998).

Reza Banakar and Max Travers, Theory and Method in Socio-Legal Research (Hart, 2005); Peter Cane and Herbert Kritzer, The Oxford Handbook of Empirical Legal Research (Oxford University Press, 2010); Richard L. Abel, "Law and Society: Project and Practice," Annual Review of Law and Social Science 6 (2010); Javier Treviño, “The Sociology of Law in Global Perspective,” The American Sociologist 32.2 (2001); Stewart Macaulay, "Non-Contractual Relations in Business: A Preliminary Study," American Sociological Review 28.1 (1963).

5 Empirical studies on law in post-Soviet context remain rare. They include most works by Professor Kathryn Hendley, such as Kathryn Hendley, "Enforcing Judgments in Russian Economic Courts," Post-Soviet Affairs 20.1 (2004); “'Telephone Law' and the 'Rule of Law': The Russian Case, ” Hague Journal on the Rule of Law 1.2 (2009); "Resolving Problems among Neighbors in Post-Soviet Russia: Uncovering the Norms of the Pod'ezd," Law \& Social Inquiry 36.2 (2011); "Mobilizing Law in Contemporary Russia: The Evolution of Disputes over Home Repair Projects," The American Journal of Comparative Law 58.3 (2010). Empirical studies by others on Russian law include, for example, Timothy Frye, “Two Faces of Russian Courts: Evidence from a Survey of Company Managers," East European Constitutional Review 11.1-2 (2002); Marina Kurkchiyan, "Russian Legal Culture: An Analysis of Adaptive Response to an Institutional Transplant," Law and Social Inquiry 34.2 (2009); "What to Expect from Institutional Transplants? An Experience of Setting up Media Self-Regulation in Russia and Bosnia," International Journal of Law in Context 8.1 (2012); Jordan Gans-Morse, "Threats to Property Rights in Russia: From Private Coercion to State Aggression," Post-Soviet Affairs 28.3 (2012). Empirical studies on law in Ukraine are even more rare; to our knowledge, they include the following: Iryna Akimova and Gerhard Schwodiauer, "The Effect of Trust in Courts on the Performance of Ukrainian SMEs," in Trust and Entrepreneurship: A West-East Perspective, ed. H. H. Hohmann and F. Welter (Cheltenham: Edward Elgar Publishing, 2005); Marina Kurkchiyan, "Justice through Bureaucracy: The Ukrainian Model," Social \& Legal Studies 22.4 (2013); Tatiana Kyselova, "Legal Transformations of Business Disputes in Post-Soviet Ukraine," Oñati Socio-Legal Series 1.6 (2011); "Comparing Contracts through a Socio-Legal Approach: Case Study of Ukraine," Journal of Comparative Law 8.1 (2013); “Dualism of Ukrainian Commercial Courts: Exploratory Study," Hague Journal on the Rule of Law 6.2 (2014); "Pretenziia Dispute Resolution in Ukraine: Formal and Informal Transformation," Review of Central and East European Law 40.1 (2015). 
everyday patterns of contract enforcement and dispute resolution in Ukrainian businesses. ${ }^{6}$ Apart from the typical contractual pattern prevalent at the researched firms, it was impossible in that project to overlook the exceptional pattern that manifested itself in relationships involving the state. Although this pattern appeared only in a minority of relationships (up to $5 \%$ of all contracts), it was clearly troublesome for those businesses. This article analyses in more detail the state-business link that emerged from this pattern.

The relationship between the state and business in Ukraine remains an under-researched topic. If this link is at all discussed, it is addressed at the macro-level, ${ }^{7}$ in particular as an interaction of the state power structures and certain groups of businesses - either large industrial groups ${ }^{8}$ or small and medium enterprises. ${ }^{9}$ Quite a few studies have been devoted to the development and reform of public procurement, as public procurement is considered to be one of the most corrupt components of state-business relations in Ukraine. ${ }^{10}$ The statebusiness link in these studies is analyzed from the top down, i.e., the state is seen as operating primarily in the capacity of a sovereign and businesses are seen in the capacity of subordinated subjects. In contrast, this study presents a micro-level, bottom-up account of the state-business link through the eyes of Ukrainian businesses.

To unravel the nuances of the state involvement in business, this article begins with an outline of the methodology employed in this study. Then, it surveys existing literature on the role of state in post-Soviet business and society. The main part of the article presents the empirical findings of a case study and analyzes how Ukrainian businesses perceive the state and how they actually pursue contracting with state parties. It demonstrates how defective contract enforcement, illegal practices during public tenders, kickbacks from suppliers, personal relations between trading partners and state administrative resources are used in contractual relations involving the state agencies, state-owned enterprises and quasi-state private firms.

6 “Contract Enforcement in Post-Soviet Ukrainian Business," (University of Oxford, 2012).

7 Joel Hellman and Mark Schankerman, "Intervention, Corruption and Capture: The Nexus between Enterprises and the State," Economics of Transition 8.3 (2000); Simon Johnson, John McMillan, and Christopher Woodruff, "Entrepreneurs and the Ordering of Institutional Reform: Poland, Slovakia, Romania, Russia and Ukraine Compared," 1.

8 Serhiy Kudelia, "The Sources of Continuity and Change of Ukraine's Incomplete State," Communist and Post-Communist Studies 45.3-4 (2012); Taras Kuzio, "Crime, Politics and Business in 199 os Ukraine," 47.2 (2014).

9 Akimova and Schwodiauer, "The Effect of Trust in Courts on the Performance of Ukrainian SMEs," David Smallbone and Friederike Welter, "The Role of Government in SME Development in Transition Economies," International Small Business Journal 19.4 (2001).

10 Susan Stewart, "Public Procurement Reform in Ukraine: The Implications of Neopatrimonialism for External Actors," Demokratizatsiia 21.2 (2013); Simon Evenett and Bernard Hoekman, "International Cooperation and the Reform of Public Procurement Policies," World Bank Policy Research Working Paper Series 3720 (2005), accessed May 7, 2013, http://ssrn.com/abstract=821424. Åse Berit Grødeland and Aadne Aasland, "Fighting Corruption in Public Procurement in Post-Communist States: Obstacles and Solutions," Communist and Post-Communist Studies 44.1 (2011). 
This article concludes with a summary of the findings and their broader implications for postMaidan Ukrainian business and society.

\section{Methodology}

This article relies upon the empirical findings of a qualitative case study of three firms and their trading partners in Eastern Ukraine in 2007-2011.

The selection of the firms for this case study has been designed to provide a contrast. The three firms - a Plant, a Farm and a Café — differ from one another in most aspects: size, age, economic sector, ownership and organizational structure, customer base, staff experience, etc. (see Table 1, Appendix 1). First, the study sought variation in firm size, which has been shown by several studies to be decisive in determining contractual patterns. ${ }^{11}$ Therefore, the Café with five employees, the Farm with over fifty employees, and the industrial Plant with more than five hundred employees were chosen. According to Ukrainian law, ${ }^{12}$ as well as under international classifications, ${ }^{13}$ this spectrum of enterprise sizes corresponds to small, medium, and large businesses, respectively.

Furthermore, the selection of the firms followed the logic of an "average Ukrainian firm" within a range of sizes. The 2013 World Bank Enterprise Survey indicates that most large Ukrainian enterprises are concentrated in the manufacturing sector, whereas the trade and service sectors are dominated by small- and medium-sized firms. ${ }^{14}$ Therefore, the large Plant represented industrial manufacture, the medium Farm - agriculture, and the small Café services. The markets of the respective firms, in general terms, reflect the underlying structure of the Ukrainian economy with its limited competition and low product customization. Located in a single region of Eastern Ukraine, the three firms operated in similar political and economic conditions, thereby obviating the influence of regional differences. Finally, the selection of the firms deliberately avoided firms with extreme characteristics. As a result, all three firms could be characterized as middle-range businesses.

Arne Bigsten et al., “Contract Flexibility and Dispute Resolution in African Manufacturing,” Journal of Development Studies 36.4 (2000); Elena Vinogradova, "The Big Issue of Small Businesses: Contract Enforcement in the New Russia” (University of Maryland, 2005); IFC, "Ukraine Commercial Dispute Resolution Study: Researching Commercial Disputes among Ukrainian Companies," (International Finance Corporation, World Bank Group, 2007).

Based on the number of employees, small enterprises are those employing less than fifty people; large enterprises employ more than 25 o people with annual profit from sales more than UAH 100,000,000 (USD 10,000,000 at the exchange rate 1 USD = 10 UAH in 2010). Art. 63 of the Commercial Code of Ukraine [Gospodarskyi kodeks Ukrainy] (January 16, 2003) No.436-IV, Vidomosti Verkhovnoi Rady Ukrayiny (2003) Nos.18, 19-20, 21-22, item 144.

13 The World Bank Enterprise Surveys' classification treats enterprise with $5^{-19}$ employees as a small enterprise, 20-99 as a medium enterprise, and more than 100 employees as a large enterprise. See http://www.enterprisesurveys.org/data/exploreeconomies/2013/ukraine, accessed March 27, 2015. 
The main inquiry of this research was based on a longitudinal in-depth case study, which is the most suitable for an interpretive perspective. ${ }^{15}$ The primary sources of empirical data consisted of semi-structured interviews, written documents and on-site observations at the three researched firms and their selected trading partners. ${ }^{16}$ During each year of the five years encompassing the 2007-2011 time-frame of this study, the author undertook a twomonth placement with each of these three firms and conducted semi-structured face-to-face interviews with the owners, general director, department heads, operational-level supply and sales managers, lawyers, salespeople and workers.

Inquiries were not limited to the firms under research, however. The author also attempted to understand the firms' relations with their trading partners who were also interviewed during the fieldwork. Furthermore, as business experts, the interviewees were encouraged to comment on the general practices prevalent in their respective industries. During the ten months of this research (spread over the five-year-research term), the author conducted a total of 102 interviews with employees of the researched firms and 12 interviews with their trading partners; certain key sources have been interviewed more than 20 times. ${ }^{17}$

Interviewing also was supplemented by on-site observations at the researched firms, as well as in commercial courts, by examining relevant written records - including, inter alia, contracts, ${ }^{18}$ written correspondence, ${ }^{19}$ letters of pretenziia, ${ }^{20}$ and records of court cases ${ }^{21}$ — and statistical information from the accounting systems of the researched firms.

15 According to Banakar and Travers, "from an interpretive perspective, it is usually preferable to conduct one in-depth case study, based on a long period of fieldwork, as opposed to spending shorter periods of time in two or more settings." Banakar and Travers, Theory and Method in Socio-Legal Research, 21.

16 During the fieldwork in 2007-2011, three of the researched firms signed contracts with approximately 500-6oo buyers and suppliers annually. The following documents concerning business relations with their buyers and suppliers were studied: records of 4,299 transactions; 251 written contracts; 92 letters of pretenziia written by (and to) the buyers and suppliers of the researched firms; 73 letters of correspondence; 19 files for court cases involving the researched firms and their trading partners as plaintiffs or defendants in Ukrainian commercial courts. All interviews contained a series of questions regarding the buyers and suppliers of the researched firms. 12 in-depth interviews were specifically designed for and conducted with selected trading partners of the firms being studied.

17 The number of interviews conducted at the Plant and its trading partners was 64; at the Farm and its trading partners: 30 ; and at the Café and its trading partners: 20.

18 At the Plant, 165 contracts were examined; at the Farm: 81; and at the Café: 5 .

19 At the Plant, letters to and from trading partners (including state agencies that acted in a commercial capacity): 28; at the Farm: 11; and at the Café: 34 .

20 At the Plant, 35 pretenziia letters; at the Farm: 4; and at the Café: 1. Pretenziia is a dispute resolution institution that proliferated during Soviet times and still remains used in contemporary Ukrainian business. See, Kyselova, "Pretenziia Dispute Resolution in Ukraine: Formal and Informal Transformation."

21 At the Plant, 14 courts cases; at the Farm: 3; and at the Café: 2. These court cases involved the researched firms as plaintiffs or defendants in Ukrainian commercial courts of all instances; all the 
These data were augmented by information from the secondary sources referenced in this article, such as relevant legislative acts, Ukrainian mass media and Ukrainian internet sites. The Ukrainian Unified National Registry of Court Judgments also was used to retrieve the judgments involving the researched firms. ${ }^{22}$ Such depth and richness of data stemming from varied sources, collected over a five-year period, provided a unique opportunity to render some conclusions about dispute-resolution practices prevalent in low-technology, moderately competitive sectors of the Ukrainian economy. At the same time, it is acknowledged that any attempts to generalize about the conclusions of this study must be made with the caution intrinsic to qualitative research methods. ${ }^{23}$ Other patterns may occur in Ukraine's innovative or highly-competitive industries, but this will require further research.

The following introduces each firm:

The Plant is a restructured former Soviet industrial enterprise that produces cable for the coal, metal, energy, and construction industries. The Plant is organized as a hierarchical manufacturing company with decision-making vested in the General Director. In addition to the production workshops, the Plant consists of eight other departments, including a legal department employing two lawyers. The percentage of sales contract breaches did not exceed $9 \%$ of transactions even during the financial crisis in 2008-2009. In contrast, payment delays by the Plant to its suppliers became a profound problem in the aftermath of the crisis. The Plant regularly delayed up to $80 \%$ of payments under its trade credit contracts in 2009-2011. As a result, the number of pre-trial claims [pretenziia] against the Plant increased fivefold in 2011 compared to 2008, and the number of court cases rose from zero in 2008 to four in 2011.

The Farm is a medium to small business that rents land plots from individual farmers and produces wheat, corn, millet, and sunflower seeds. The management is concentrated in the hands of the Owner and the Manager. Fortunately, the economic crisis of 2008 did not

cases were brought to final judgments. For an analysis of the experiences of the researched firms in interacting with the courts, see "Comparing Contracts through a Socio-Legal Approach: Case Study of Ukraine."

The database of the Ukrainian Unified National Registry of Court Judgments, available at http://www.reyestr.court.gov.ua. The Registry was set up under the Law of Ukraine "On Access to Court Decisions," ["Pro dostup do sudovykh rishen,"] (December 22, 2005) No.3262-IV, Vidomosti Verkhovnoi Rady Ukrainy (2006) No.15, item 128. However, it should be noted that although it was launched in 2006, the Registry is not (yet) a particularly reliable source of precise case-law data. Numerous critical reports in Ukrainian mass media point to: the Registry's alleged failure to include a significant number of court decisions (reportedly, the most controversial ones); numerous mistakes in the titles of the courts and, also, the names of the judges; searches which did not function properly; and frequent out-of-order lapses in the system's operation. For example, out of 94,6oo decisions on the merits of the cases rendered by local commercial courts in 2011 (see court statistics at the official website of the Ukrainian judicial administration, available at http://court.gov.ua/ sudova_statystyka/), the Registry includes slightly more than approximately two-thirds thereof, i.e., 75,193 decisions (information retrieved from the Ukrainian Unified National Registry of Court Judgments on 31 March 2015). 
affect the demand for agricultural products. Even so, the Farm turned out to have the highest rate of contractual violations among the three firms, amounting to $13.8 \%$ of its transactions. Nevertheless, the Farm appeared in commercial courts only three times in its existence.

The Café is a small business operated by a sole entrepreneur. Her employees sell and serve basic snacks, beer and soft drinks to consumers from a street kiosk and a café. The Café had the fewest contractual problems in comparison with the Plant and the Farm, amounting only to o.6\% of transactions. Suing vendors in the courts was unthinkable for the Cafés Owner. Even so, she became involved in a protracted conflict with her landlord that resulted in two lawsuits and one criminal case against the Café's Owner.

The appendix provides a summary of the background information about the firms researched in this study.

\section{The Image of the Post-Soviet State as a "Grabbing Hand": Literature Review}

The rapid collapse of the Soviet system opened up unprecedented window of opportunities for individuals' rent-seeking aspirations - "incentives to spend time and effort to divert, for their own uses, part of the surplus of market activities or to guard their shares of surplus against appropriate activities on the part of others." ${ }^{24}$ Those who were entrenched for decades in the informal Soviet economy unsurprisingly seized the opportunity as soon as possible. The underdeveloped institutional environment could offer very few constraints against these rentseeking activities.

As a result, Ukraine, alongside Russia and a few other post-Soviet societies, approached the model of a rent-seeking society. In such societies, the state apparatus can be seen a major means to appropriate and redistribute wealth where the powers of the state and business converge uniquely. ${ }^{25}$ While there is a disagreement in recent academic literature as to whether this convergence could be characterized as a capturing of the state by business ${ }^{26}$ or a capturing of business by the state, ${ }^{27}$ or even a bargaining and exchange model between politicians and

24 Guillaume Cheikbossian, "Property Rights, Rent-Seeking and Aggregate Outcomes in Transition Economies," Economic Systems 27 (2003): 272.

25 Vladimir Dubrovskiy, Janusz Szyrmer, and William Graves, "The Reform Driving Forces in a RentSeeking Society: Lessons from the Ukrainian Transition. Country Study within the Global Research Project of Understanding Reforms, the Global Development Network," CEU Policy Documentation Center (2008), accessed May 7, 2013, http://pdc.ceu.hu/archive/oooo6885/o1/CASE_Reform-drivingforces_2007.pdf.

26 Joel S. Hellman, Geraint Jones, and Daniel Kaufmann, "Seize the State, Seize the Day: State Capture and Influence in Transition Economies," Journal of Comparative Economics 31.4 (2003); Ichiro Iwasaki and Taku Suzuki, "Transition Strategy, Corporate Exploitation, and State Capture: An Empirical Analysis of the Former Soviet States," Communist and Post-Communist Studies 40.4 (2007); John Gould and Yaroslav Hetman, "Market Democracy Unleashed? Business Elites and the Crisis of Competitive Authoritarianism in Ukraine," Business and Politics 10.2 (2008).

27 Philip Hanson and Elizabeth Teague, "Big Business and the State in Russia," Europe-Asia Studies 57.5 (2005); Andrei Yakovlev, "The Evolution of Business-State Interaction in Russia: From State 
business, ${ }^{28}$ it is clear that the mixture is complex and deeply embedded in social relations. According to Oleinik, these relationships develop in both directions - property rights converge into political power, and simultaneously political power transforms into property rights, resulting in the concept of "power-property."29

Increasingly, researchers explore the adverse impact of state capture upon economies in transition. State capture was shown to open up a whole set of business opportunities to the administrative class of bureaucrats and private businesses, such as access to important business information and enhanced protection from other bureaucrats, ${ }^{30}$ licensing advantages, ${ }^{31}$ state subsidies, ${ }^{32}$ governmental contracts, tax privileges, and other tangible benefits. ${ }^{33}$ Many bureaucrats have successfully established and managed their own businesses, although these are formally registered as owned by their close relatives. According to Ledyaev, "for some, their official position becomes just an instrument in their business career." ${ }^{34}$

While quantitative studies demonstrate that captor firms enjoyed more protection of their own property rights and exhibited a superior firm performance, capture adversely affects small business growth, results in weaker economic performance and reduced foreign direct investment. ${ }^{35}$ Initially the state-owned enterprises that inherited the network capital of the Soviet system were the main beneficiaries of state capture; later, the newly created large private firms made a conscious choice towards state capture as a major competitive business strategy. ${ }^{36}$

Thus, in a rent-seeking society the state can be seen as a lucrative source of power, open for competition and manipulation by the private actors. This type of power was widely recognized by elites and ordinary people alike by coining the term "administrative resources" - the use of bureaucratic hierarchies and the material resources of public institutions to advance private

Capture to Business Capture?" Europe-Asian Studies 58.7 (2006).

28

Anton Oleinik, "A Distrustful Economy: An Inquiry into Foundations of the Russian Market,"

Journal of Economic Issues 39.1 (2005); Timothy Frye and Ichiro Iwasaki, "Government Directors and

Business-State Relations in Russia," European Journal of Political Economy 27.4 (2011).

29 Oleinik, "A Distrustful Economy," 14-15.

30 Akimova and Schwodiauer, "The Effect of Trust in Courts on the Performance of Ukrainian SMEs."

$31 \quad$ Robert Hoskisson et al., "Strategy in Emerging Economies," Academy of Management Journal (200o).

32 Michael McFaul, "State Power, Institutional Change, and the Politics of Privatization in Russia," World Politics 47 (1995).

33 Bat Batjargal, "Social Capital and Entrepreneurial Performance in Russia: A Longitudinal Study," Organization Studies 24.4 (2003).

34 Valeri Ledyaev, "Domination, Power and Authority in Russia: Basic Characteristics and Forms," Journal of Communist Studies and Transition Politics 24.1 (2008): 20.

35 Nathan Jensen, "Economic Reform, State Capture, and International Investment in Transition Economies," Journal of International Development 14.7 (2002); Hellman, Jones, and Kaufmann, “Seize the State, Seize the Day: State Capture and Influence in Transition Economies"; Irina Slinko, Evgeny Yakovlev, and Ekaterina Zhuravskaya, "Laws for Sale: Evidence from Russia," American Law and Economics Review 7.1 (2005); Yakovlev, “The Evolution of Business-State Interaction in Russia."

36 Hellman and Kaufmann, "Seize the State, Seize the Day: State Capture and Influence in Transition Economies," 751 . 
gains. ${ }^{37}$ Although the term initially referred to political actors' unofficial advancement of electoral gains, it was also stretched to encompass any sphere, including the judicial system, economic production and exchange. For example, according to Kurkchiyan, "administrative resources are usually defined as a lever that is often applied high up in the judiciary, by politicians, officials and business managers." 38

Administrative resources have been studied by post-Soviet researchers in spheres as diverse as electoral politics, judiciary and business, and have been demonstrated to operate through coercive measures such as instigated inspections of businesses by state organs, ${ }^{39}$ criminal prosecution, ${ }^{40}$ and withdrawal of access to public goods..$^{41}$ The nature of administrative resources was generally viewed as coercive and deductive. Allina-Pisano, who studied administrative resources within electoral campaigns in Ukraine, demonstrated that, in contrast to vote buying, administrative resources operate through threats to withdraw individuals' and firms' access to public goods such as salaries, public infrastructure, public education and markets in consumer goods. ${ }^{42}$

Administrative resources were shown to be invoked as a major weapon by private as well as state actors to attack the property rights of businesses through extortions and hostile takeovers - corporate raids. ${ }^{43}$ In his research of Russian businesses, Gans-Morse documented that state officials were "increasingly initiating attacks on firms themselves rather than merely offering property security services to private actors." ${ }^{\prime 4}$

Two studies have highlighted the use of administrative resources in contract enforcement among businesses in Russia. ${ }^{45}$ Both discovered the strategy of turning to state officials for help in solving problems with customers and suppliers, but documented its decline in contemporary Russia. Hendley and her colleagues referred to this transactional strategy of the Russian

37 Jessica Allina-Pisano, "Social Contracts and Authoritarian Projects in Post-Soviet Space: The Use of Administrative Resource," Communist and Post-Communist Studies 43.4 (2010): 374.

38 Marina Kurkchiyan, "The Impact of the Transition on the Role of Law in Russia," in Explorations in Legal Cultures, ed. F. Bruinsma and D. Nelken (Reed Business BV, 2007), 8o.

39 Vinogradova, "The Big Issue of Small Businesses: Contract Enforcement in the New Russia."

40 Jordan Gans-Morse, "Building Property Rights: Capitalists and the Demand for Law in Post-Soviet Russia" (University of California, 2011).

41 Allina-Pisano, "Social Contracts and Authoritarian Projects in Post-Soviet Space: The Use of Administrative Resource."

Allina-Pisano, "Social Contracts and Authoritarian Projects in Post-Soviet Space," 374.

43 Vadim Volkov, "Hostile Enterprise Takeovers: Russian Economy in 1998-2002," Review of Central and East European Law 29.4 (2004); Stanislav Markus, "Secure Property as a Bottom-up Process: Firms, Stakeholders, and Predators in Weak States," World Politics 64. 2 (2012); Matthew Rojansky, "Corporate Raiding in Ukraine: Prevention, Defense, and Policy Reform," Review of Central and East European Law 39.3-4 (2014).

44 Gans-Morse, "Building Property Rights: Capitalists and the Demand for Law in Post-Soviet Russia," 227.

45 Kathryn Hendley, Peter Murrell, and Randi Ryterman, "Law, Relationships and Private Enforcement: Transactional Strategies of Russian Enterprises," Europe-Asia Studies 52.4 (2000); Vinogradova, "The Big Issue of Small Businesses." 
businesses as "administrative levers of the state" 46 and Vinogradova — as "the threat of punitive actions by state officials." ${ }^{27}$ According to Vinogradova:

Firms that use, or used, the threat of punitive actions by state officials as a contract enforcement strategy capitalize on different kinds of connections with different results. They can bribe low level officials from state regulatory organizations to conduct unscheduled check-ups and then bury the offender in fees and fines; or they can use high-level state officials to threaten the offender in various ways. ${ }^{48}$

To conclude, these accounts convey the image of a post-Soviet state as a violent power of merged political and economic interests that manipulates its administrative resources in order to extract rents from businesses or to threaten their property rights.

\section{The State Viewed through the Eyes of Business - Complete Bespredel}

"There remained only one bandit in this country — the state."49

The predatory role of the Ukrainian state described in the academic literature on the postSoviet transition has been corroborated by the findings of this case study. The interviewers compared the Ukrainian state under the Yushchenko and the Yanukovych governments to bespredel. The same word - bespredel — was used equally by the interviewees when they referred to the government or state agencies during both political regimes. There is no adequate translation of this word into English. In the latest edition of the Ozhegov Russian Language Dictionary it is defined as an extreme degree of illegality and disorder. ${ }^{50}$ Researchers of the criminal sub-cultures in Russia treat bespredel as limitlessness or lawlessness - an absence of any moral or legal regulation of social life..$^{51}$ As many other expressions that popularly characterize state and society in the former Soviet Union, the word came from criminal jargon of the late 198 os. Then it meant the fierce violation of the thieves' laws within the criminal community.52 After the breakup of the Soviet Union, the word bespredel came into usage in conjunction with the state and its law enforcement agencies, in particular the police and the courts. ${ }^{53}$

\footnotetext{
46 Hendley and Ryterman, "Law, Relationships and Private Enforcement," 642-43.

47 Vinogradova, "The Big Issue of Small Businesses," $145^{-5}$ o.

48 Vinogradova, “The Big Issue of Small Businesses," 149.

49 Interview with the top manager of a construction company, one of the Plant's buyers (July 27, 2007).

$5^{\circ}$ Ozhegov Dictionary On-line, accessed March 31, 2015,

http://enc-dic.com/ozhegov/Bespredel-1584.html

$5^{1} \quad$ Svetlana Stephenson, “The Kazan Leviathan: Russian Street Gangs as Agents of Social Order,"

The Sociological Review 59.2 (2011).

$5^{2}$ Leonid Nikitinskii, "Bespredel," ["Bespredel,"] Ogoniok, August 6-13, 1988.

53 Vladimir Kartsev, Zhirinovsky: An Insider's Account of Yeltsin's Chief Rival and Bespredel the New

Russian Roulette (New York: Columbia University Press, 2013); Maxim Glikin, Militsia i bespredel

[Police and Bespredel] (Moscow: Tsentrpoligraph, 1998); G. Aleksandrov and I. Kuznetsova,
} 
By the end of the fieldwork for this research, in 2011, the state authorities in Ukraine were seen by the interviewees as "complete bespredel" [polnyi bespredel]. While the state in Russia, for example, was believed to be a "strong state" rooted in the Putin's "vertical" of power, ${ }^{54}$ the Ukrainian state was seen by the interviewees of this study as failed and disintegrated. When the author asked interviewees a direct question about the role of the state in their business, all replied that in fact there was no state in Ukraine: "Do we have a state? The state is an entity which you give your taxes to, but in our country the state only extorts." 55

The Café Owner simply stressed: "No, we do not have a state."56 The Head of the Plant's economic security complained that "we have no vertical of power," apparently recalling Putin's version of the strong state. ${ }^{57}$

State disintegration was seen as driven by its capture by large businesses. The state presented an amorphous but powerful resource to anyone who possessed enough strength to capture it. The non-transparent system of grain quotas in agriculture and governmental "cleansings" of the copper market were offered as examples of state capture by selected large business.

The Ukrainian government introduced grain export quotas in 2006 in order to respond to natural harvest fluctuations, to protect the internal agricultural market and to control food prices. The quotas were reintroduced on ad hoc basis in 2008 and 2011. ${ }^{58}$ The Farm Owner complained that the lion's share of the quotas always went to a few selected exporters who were closest to the government and that this increased costs for small and medium producers. ${ }^{59}$

The example of the "cleansing" of the copper market was also instructive because it also illustrated the high level of unpredictability of state policies. In November 2010, the Plant faced a tax inspection that was clearly directed against certain suppliers of its copper. The lawyers explained:

The whole market of copper in Ukraine is almost all black. There are only two legal producers of copper rod. Under Yushchenko the firms importing "black" copper rod proliferated. Now when Yanukovych came in power, they "clean" the market. Those who have no governmental krysha (roof; a cover) are being destroyed. The tax inspectorate initiated criminal charges against them. So they [the state] make the Plant buy from those few suppliers who have got a krysha and only through

“Bespredel v Pogonakh Nepobedim?" ["Is Bespredel in Shoulder Straps Invincible?"] Argumenty i Fakty 40, 2013, 12-13.

Vladimir Gel'man and Sergei Ryzhenkov, "Local Regimes, Sub-National Governance and the 'Power Vertical' in Contemporary Russia," Europe-Asia Studies 63.3 (2011); Andrew Monaghan, "The Vertikal: Power and Authority in Russia," International Affairs 88.1 (2012). Interview with the Head of the Legal Department, the Plant (December 21, 2010).

56 Interview with the owner of the Café (October 7, 2008).

57 Interview with the Vice-Director for Economic Security, the Plant (November 27, 2008).

$5^{8}$ Bernhard Brummer, Stephan von Cramon-Taubadel, and Sergiy Zorya, "The Impact of Market and Policy Instability on Price Transmission between Wheat and Flour in Ukraine," European Review of Agricultural Economics 36.2 (2009). 
prepayment. If you buy under trade credit from those without a krysha, the tax inspectorate invalidates the contracts on public policy grounds. ${ }^{60}$

It was not clear whether this account by the Head of Legal Department was accurate, as the author has not found any other supporting information. However, it showed how most powerful private businesses with links to the state could exploit state resources to their advantage.

Another feature characteristic of the state bespredel was extortion from businesses. Interviewees stressed that the state only skins [sdiraiet shkuru], extorts [vymogaiet], strangles [dushit] and squeezes [otzhimaiet]. ${ }^{61}$ Extortions could take the form of attacks on property rights, "voluntary" donations to state agencies or indirect regular tributes in the form of administrative fines.

The Café Owner experienced appropriation attacks by state officials on her property twice during the period of my 2007-2011 fieldwork. In both cases, municipal authorities used the whole arsenal of intimidating inspections through law enforcement and regulatory agencies, outrageous fines, court litigation and criminal charges against her. ${ }^{62}$

Donations to the construction of the city football stadium, the organization of conferences by the local tax administration, and the purchase of an automobile for the local governor were offered as examples of the "voluntary" contributions that businesses were asked to make. Only a few businesses could afford to resist them. Taking into account the relatively insignificant cost of the requests, fulfilling them without asking questions was easier than resisting them. Furthermore, the interviewees noted the declining use of this fundraising strategy by the local authorities. ${ }^{63}$

The major method of state extortion was fines imposed upon businesses during regular, intimidating inspections by the tax inspectorate and numerous other state agencies. Although Ukrainian law restricted the financial inspections of a business entity to one peryear and required a minimum of ten days notice, ${ }^{64}$ which was seen as a great relief for business, non-financial inspections by other agencies, such as fire safety, sanitation, occupational safety, and many others remained unrestricted. Most state agencies had at least two levels of organization - the city and the oblast (region). Therefore, they could inspect businesses and impose fines at least

6o Interview with the Head of the Legal Department, the Plant (December 23, 2010).

61 Interview with the Vice-Director for Economic Security, the Plant (December 10, 2009); interview with the salesman A, the Café (December 8, 2008); interview with the Director of the technology innovation company, one of the Plant's suppliers (October 13, 2011).

62 Interviews with the owner of the Café (November 4, 2008; October 20, 2010; and September 7, 2011).

63 Interview with the owner of the Café (September 7, 2011); interview with the Director of the technology innovation company, one of the Plant's suppliers (October 13, 2011); interview with the owner of the Farm (December 23, 2011); interview with the Head of the Legal Department, the Plant (December 27, 2011); interview with the Vice-Director of the bakery, one of the Farm's buyers (December 15, 2010).

64 These provisions, which have been in force during the fieldwork for this research, are currently codified in the 2012 Tax Code. See, Podatkovyi Kodeks Ukrainy [Tax Code of Ukraine] (December 2, 2010) No.2755-VI, Vidomosti Verkhovnoi Rady Ukrainy (2011) Nos.13-14, 15-16, 17, item 112. 
twice for each matter. As the Head of the Plant's Legal Department remarked, "they simply do not give us a chance to work." 65

Implicit and explicit threats became part of the inspections. In some cases, tax inspectors were not able to justify the high amount of the fines that they were obliged to impose under their "plan." ${ }^{\prime \prime 6}$ When the actual tax violations identified by the inspector were not sufficient to cover the amount of the "planned" fine, the tax administration threatened even higher fines and criminal charges. According to the interviewees, in these circumstances some businesses surrendered quickly — the owners simply destroyed certain accounting documents themselves so that the next morning the tax inspector documented the violation and calculated the required amount of fines. Others dared to resist and to sue the tax administration in the administrative court. One of the businesses successfully had a UAH 140,000 fine repealed through the administrative court and was immediately confronted with a second fine of UAH 400,000 and threatened with a third fine of UAH 1,00o,ooo. Within a year, all of the fines were revoked through court procedures in the first, appellate and high instances of the administrative courts, but this cost quite a lot. ${ }^{67}$

On top of this, relations with the tax inspectors were sometimes influenced by personal sympathies. The wrong treatment of the tax inspector and a graceless tone of conversation during the onsite inspection could cost the company under inspection huge fines, protracted litigation and criminal charges. Stories of this kind abound.

Finally, state bespredel was characterized by the extreme uncertainty and lack of the predictable rules in relationships with the state authorities. In the face of incomprehensible and contradictory legislation, the logic of decision-making by the disintegrated state was completely unclear. The interviewees were not able to explain the rationale even behind certain positive decisions by the state agencies in their favor.

Informal rules governing unofficial relations between the businesses and local state authorities, namely the tax inspectorates, were reported to be in constant flux. The consensus amongst interviewees was that absolutely all businesses in Ukraine, except perhaps those that are foreign-owned, were involved in tax evasion and could be subjected to fines relatively legitimately. Therefore, most Ukrainian businesses were reported to maintain "good relations" with their tax inspectors and the heads of the local tax inspectorates who were regularly treated with the gifts in kind and in envelopes. ${ }^{68}$

According to the interviewees at all the three researched firms, before 2010, under the Yushchenko government, the informal rules governing relations with tax inspectorates allowed for renegotiations and the decrease of fines, provided the bribe was paid in cash. After

65 Interview with the Head of the Legal Department, the Plant (August 3, 2007).

66 Although planned economy does not exist in Ukraine as such, interviewees suggested that the state tax inspectorates still operated under some kind of Soviet-style plan from central authorities that prescribed the amount of fines to be collected from businesses.

67 Interview with the Head of the Legal Department, the Plant (December 27, 2011).

68 Interview with the lawyer, the Plant (November 25, 2009); interview with the manager of the Farm (December 8, 2009); interview with the owner of the Farm (December 8, 2009); interview with the assistant to the Vice-Director for Economic Security, the Plant (December 23, 2010). 
Yanukovych came into power in 2010 the rules were unilaterally changed - all of a sudden, tax inspectors stopped accepting bribes. Instead, they demanded outrageously high fines to be paid to the state budgets in an apparent effort to increase state revenues; any negotiations to decrease these fines for businesses became fruitless. ${ }^{69}$

To sum up, Ukrainian businesses in this research termed the state as bespredel disintegrated and scattered but unrestricted, unpredictable and violent power that relies upon administrative resources of the state to extort rent from businesses that do not belong to the inner circle of those in power. This image of the state was equally characteristic of the Yushchenko regime as well as the Yanukovych regime. Thus, both the academic literature and the interviewees in this study picture the state as a predator and the average small and medium businesses as its victims. However, probing beyond the perceptions of the interviewees in this study into actual business relations reveals a slightly different picture that is explored in more detail in the following section.

\section{State as a Trading Partner: Benefits and Risks}

Apart from the inspections and other encounters with the state authorities in their public capacity, the Ukrainian businesses studied in this research had to routinely deal with the state in its commercial capacity. All of the researched firms contracted with the state-owned enterprises and state agencies on a permanent basis or from time to time. Furthermore, the link to the state manifested itself in the business relationships of the researched firms with the quasi-state private firms, which were referred to as "muddy" by the interviewees.

It is an acknowledged fact that many, if not most, firms in Ukrainian business retain some links to state officials of various ranks, which was often referred to as a "roof" [krysha] — criminal slang for political protection. ${ }^{70}$ For example, the Café Owner was connected to a former KGB officer through her husband's family, and the Farm Owner was himself elected as a member from the governing Party of Regions to the local district council. However, "muddy" [mutnyi] private firms were those who consciously relied on a link to the local government in their private contractual relations with their trading partners. They were seen as quasi-stateowned businesses that were able and willing to manipulate the machinery of the state to gain a competitive advantage over other businesses.

The following accounts unravel the nuances of the business-to-business relationships of the researched companies and state agencies, state-owned enterprises and "muddy" companies.

69 To feel the difference caused by this change of rules here are some numbers. In the result of 2009 tax inspection one unnamed business was threatened with a fine of $\mathrm{UAH} 58$,ooo. Informal negotiations with the head of the local tax department resulted in UAH 10,000 paid to the budget and 8,00o in cash as a bribe. In 2010, after the elections and the change of the heads of the local tax inspectorates, the fine imposed upon this business raised to UAH 87,00o paid to the state budget and no bribes accepted to decrease this fine. In 2011 the informal link was restored and the company ended up with only 80,00o in fines, while others had to contribute almost twice as much. Interview with the Head of the Legal Department, the Plant (December 27, 2011). 


\section{State as a "Helping Hand"}

Although this research identified only one relationship where the state performed a role of a "helping hand"71 to businesses, for the sake of objectivity it should be mentioned here.

The positive example of collaboration with the state in business-to-business relations was reported by the Farm. Before signing the contracts with the Farm to buy its grain, all of the potential buyers routinely sampled and checked the quality of the grain through their own private laboratories or through the State Bread Inspectorate. The State Bread Inspectorate is a state agency that used to be a monopolist in laboratory examinations of grain in the Soviet Union. In 2007-2011 it operated through established branches in each region of Ukraine. Despite being owned by the state, these laboratories have generally gained a reputation for fairness and competency. Furthermore, given the increased market competition from private laboratories, the State Bread Inspectorate invested in accreditation by international organizations in the international grain trade such as GAFTA, ${ }^{72}$ ILAC, ${ }^{73}$ and SNAS. ${ }^{74}$ This has increased the level of trust in them by businesses and has imposed certain international standards on their work. Indeed, the interviewees at the Farm reported a sufficient level of trust in the technical expertise and integrity of these state agencies by treating them as the highest arbiter in disputes regarding the quality of grain:

The State Bread Inspectorate is the ultimate arbiter. Although grain elevators have their laboratories and they check the grain when we bring it to store there, elevators may cheat us. If we suspect something wrong we pay the services of the Bread Inspectorate and they come to verify the quality of stored grain..$^{75}$

Thus, the documents produced by the State Bread Inspectorate were treated by the local agricultural businesses as an undeniable proof of quality. Consequently, negotiations that followed the quality inspection never disputed the content of these documents, and disputes were always settled. Unfortunately, the collaboration of the private business with the State Bread Inspectorate remained the only positive example of the role of the state as a "helping hand" identified during the five years of field research for this study. Other encounters with the state in business-to-business relations were either clearly negative or presented a mix of risks and opportunities for private business.

\section{Deficient Enforcement of Contract with the State Actors}

Doing business with the state in Ukraine is marked by extreme uncertainty and problems with enforcing contracts. State-owned enterprises and state agencies are permanently underfinanced

72 The Grain and Feed Trade Association, accessed March 27, 2015, http://www.gafta.com/analysts. International Laboratory Accreditation Cooperation, accessed March 27, 2015 http://www.ilac.org/. 
by the state budgets; consequently, they are often not able to prepay their contracts and chronically delay payments to suppliers.

Furthermore, stable long-term business relationships with the state actors are undermined by frequent changes in their management. For example, it was not a secret that the directors of the Ukrainian state-owned coalmines were rotated every year or even every half a year. The interviewees at the Plant confirmed the usual practice for a new director to sign a number of contracts with the private firms, receive the goods or services under the contracts and, when his office ends, leave the contracts unpaid. Although legally the coalmine remained the same entity, a new director did not feel obliged to pay the debts of his predecessor because "it wasn't his contract."76

Another deficiency of relationships with state-owned enterprises concerned the impossibility to enforce contracts with them through the courts. Although private firms were free to sue the state-owned counterparties in commercial courts, they were not able to obtain their compensation pursuant to the judgment. Two laws promulgated by the Parliament in 2001 and $2005,{ }^{77}$ confirmed by a decision of the Ukrainian Constitutional Court, banned the mandatory disposal of assets of the state-owned enterprises whether inside or outside of bankruptcy proceedings. This left the private firms without meaningful recourse against opportunistic actions of the state-owned enterprises. ${ }^{78}$ In 2008, the European Court of Human Rights ruled that the Law on moratorium violates Article 6 of the European Convention of Human Rights. ${ }^{79}$ Following this decision, Ukraine introduced a new system of compensation for debts by the state and state-owned firms as of January $2013 .{ }^{80}$ However, even by 2015 the system remains dysfunctional due to the lack financing from the government and the aggravated political situation. ${ }^{81}$ Thus, during the fieldwork for this research and afterwards, receiving compensation

76 Interviews with Sales Manager A and Sales Manager D, the Plant (November 12, 2008); interview with the Head of the Legal Department, the Plant (August 3, 2007).

77 The Law of Ukraine "On Moratorium of Forced Seizure of Assets" ["Pro vvedennia moratoriiu na prymusovu realizatsiiu maina”] (November 29, 2001) No. 2864-III, Vidomosti Verkhovnoi Rady Ukrainy (2002) No.10, item 77; The Law of Ukraine "On Measures to Ensure Continuous Operation of the Fuel and Energy Sectors" ["Pro zakhody, spriamovani na zabezpechennia stalogo funktsionuvannia pidpryiemstv palyvno-enerhetychnoho kompleksu"] (June 23, 2005) No. 2711-IV, Vidomosti Verkhovnoi Rady Ukrainy (2005) No.33, item 430.

78 Christian Gianella and William Tompson, "Too Little Destruction, Too Little Creation: A Schumpeterian Diagnosis of Barriers to Sustained Growth in Ukraine," ECO/WKP No. 34 (2007); Marina Usheva, “Ob Ocherednoy Atake Na Moratoriy” [“Another Campaign against Moratorium,"] Yurydychna Praktyka 18 (2007).

79 ECtHR, Case of Regent Company v. Ukraine, Application no. 773/o3, Judgment of 3 April 2008.

80 The Law of Ukraine "On State Guarantees Regarding Enforcement of Court Judgements" ["Pro garantii derzhavy schodo vykonannia sudovykh rishen"] (5 June 2012) No. 49o1-VI, Vidomosti Verkhovnoi Rady Ukrainy (2013) No.17, item 158.

81 Olga Kondratyeva, "Vykonannia Sudovykh Rishen: Novi Zakony Ta Problemy," ["Enforcement of Court Judgments: New Laws and Problems,"], Iurydychny Visnyk Ukrayiny, February 2-8, 2013. 
for a state-owned enterprise's wrongs was and remains nearly impossible, even if someone managed to obtain a favorable court decision.

\section{Public Procurement Requirements as a Barrier in Relations Involving the State}

Public procurement remains an Achilles' heel of Ukrainian economic transition. ${ }^{82}$ Notwithstanding the tremendous efforts of international actors such as the World Bank, EU, and USAID, entrenched private interests of Ukrainian businesses so far have succeeded in watering down reform laws and in moving significant parts of the procurement process from the formal to informal sector. ${ }^{83}$

Questions about the participation of the researched firms in public tenders were the most difficult in this study. The Café Owner never personally took part in public tenders, and the Farm participated only a few times during its operation. Naturally, however, the Plant was directly and systematically involved in bidding for state contracts. Yet, most of the interviewees at the Plant preferred not to answer the questions about public procurement. One fact that was openly revealed concerned the practice of the Plant to avoid public tenders with state-owned enterprises and state agencies where it was possible. For example, the Plant preferred to sign eighteen contracts with one of the state-owned coal mines (instead of one) in order to escape from the public tenders. ${ }^{84}$

Other hints about public procurement came from the general discussions of the business environment in Ukraine. Most of the interviewees in such discussions suggested that generally every public tender involves illegal arrangements. The tenders were seen as "corrupt and nontransparent", and the state was reported to "make firms pay a lot for tenders." ${ }^{85}$ Finally, when asked about otkat (kickbacks from suppliers), the interviewees directly connected them to public tenders ("there are always otkat when there is a tender"86; "directors know and sponsor otkat at the large plants to pay for tenders with the state-owned enterprises" ${ }^{\prime 87}$ ).

82 In 2015, although public procurement became again a target of reforms, many violations continue to be reported in mass media. See, for example, Ukrainoiu rozpovsiudzhuetsia nova skhema makhinatsii z zakupivliamy vugillia [A New Scheme of Manipulations with State Procurement of Coal], accessed March 27, 2015, http://procurement.in.ua/ru/pages/4628/http://www.epravda.com. ua/news/2014/o8/27/486359/. "Kozhna vosma derzhavna zakupivlia vidbuvaetsia z porushenniam zakonodavstva," ["Every Eights State Tender Violates the Law,"] accessed March 27, 2015, http://www. uha.org.ua/uk/news/kozhna-vosma-zakupivlya-vidbuvaetsya-z-porushennyam-simka/; "Podolannia systemnoi koruptsii u sferi derzhavnykh zakupivel," [“Targeting Syatematic Corruption in State Procurement,"] accessed March 27, 2015, http://www.niss.gov.ua/articles/1414/.

83 Stewart, "Public Procurement Reform in Ukraine," 197.

84 The law, in force at that time, required that public tenders to be conducted when the price of the contract involving state-owned enterprise exceeded UAH 100,000. Interview with the Vice-Director for Sales, the Plant (July 17, 2007).

85 Interview with the Head of the Legal Department, the Plant (December 23, 2010).

86 Interview with the top manager of a construction company, one of the Plant's buyers (July 27, 2007).

87 Interview with the owner of the Farm (December 23, 2011). 
Apart from these hints, it was very difficult, using the methodology of this study, to delve into the public procurement issue as it was apparently very sensitive to interviewees. This fact indirectly confirms that the researched firms themselves benefitted from illegal practices during public procurement procedures.

\section{State as a Promoter of Kickbacks from Suppliers [Otkat]}

While otkat was admittedly a widely spread phenomenon in Ukrainian private business ${ }^{88}$ (up to $15 \%$ of private firms were reported by the interviewees in this study to be involved in this practice), all of the state-owned enterprises and most of the state agencies and "muddy" private businesses were believed to be systematically involved in otkat.

The Business Dictionary defines otkat - kickbacks - as a portion of an income demanded as a bribe by an official for facilitating the job or order from which the income is realized. ${ }^{89}$ In developed economies kickbacks are mostly offered by suppliers..$^{90}$ In the context of the post-Soviet transition, buyers also frequently pay otkat to their suppliers. In both cases, otkat is calculated as a percentage of the sale and is paid by goods or services, in cash or into the bank account of the person in charge of transaction - either the chief executive or the manager of the company.

88 Google search of the keyword otkat in Russian and Ukrainian language Internet revealed the number of the websites and consulting firms that expose the practice of otkat (see, for example, http:// otkatov.net.ru/technology/otkat_in_action/http://www.forbes.ru/svoi-biznes/predprinimateli/58657otkat-raspil-zanoshttp://stopotkat.net/http://www.nix.ru/documents/otkat.html), publish the books (http://otkatov.net.ru/book/) and conduct trainings both in the mastery of otkat and in the methods to fight it (https://www.youtube.com/watch?v=rjsJgeOL5h8; http://otkatov.net.ru/trainings/). All accessed March 27, 2015. Otkat among the private firms in this study was viewed by their owners as an extremely detrimental practice and entailed certain investments in its combating. To prevent otkat from being paid by suppliers to the Plant's purchase managers, the Economic Security Department of the Plant employed a person whose primary responsibility was to monitor prices and terms of delivery of inputs at the local market. She approved the contracts submitted by the purchase managers only if they incorporated the best market prices available at the moment. Contracting at the lowest possible prices eliminated or at least sufficiently decreased the likelihood of otkat. Interview with the Vice-Director for Economic Security, the Plant (November 3, 2010).

89 On-line Business Dictionary, accessed March 27, 2015, http://www.businessdictionary.com/definition/kickback.html.

9o Although the problems of internal fraud, management corruption and other kinds of white collar crimes arise from time to time in developed economies, these practices are particularly pervasive in transitional businesses. Chinese and Russian markets are frequently cited as suffering from nearly universal employee fraud and kickbacks from suppliers. According to Rozhnov, the losses of the Russian government from corruption in the public procurement system amounted to $10 \%$ of the state budget's income for 2010. See, Konstantin Rozhnov, "Russia's Bid to Stop Kickbacks Worth \$33bn a Year," Business Reporter BBC News, November 5, 2010. 
As demonstrated by this research, otkat in business relationships with the state-owned enterprises in Ukraine was openly practiced and was treated as an accepted, almost legitimate, practice. For example, the law required that the state-owned enterprises to use public tenders for large supplies. These tenders were reported to almost inevitably involve supplier's kickbacks or other illegal payments. Senior management of the private firms interested in contracting with the state enterprises was aware of the need to pay otkat; they supplied their managers with cash or authorized transfers to private accounts and generally supervised these shadow transactions. ${ }^{91}$ The Farm Owner shared his experience of dealings with otkat at the state-owned enterprises:

I think directors know and sponsor otkat at the large plants to pay for tenders with the state-owned enterprises. So, it is more or less "legitimate" [zakonnyi]. There are some state-owned enterprises where everyone knows about otkat. For example, we worked with the state company $\mathrm{X}$ and their Director took otkat from one kind of transactions, and the chief engineer - from another. All was divided. ${ }^{92}$

As was evident from the interview cited above, the scheme of shared otkat involved the separation of transactions (who takes otkat from what type of transactions). In another reported sharing scheme, an employee of lower rank who initially received the otkat payment transferred a certain percentage of it to their manager and the latter transferred it to the senior manager. The profits from otkat in this case were shared among all the employees involved in the transaction, up to the chief executive officer.

Whether the researched firms gave kickbacks remained unclear. Although most of the interviewees condemned this practice, in interviews on the matters unrelated to kickbacks, a few instances of this illegal practice at the researched firms were disclosed. For example, the Head of the Legal Department of the Plant reported that in the wake of 2008 economic crisis the workers of the Plant wrote a petition to the prosecutor office complaining that the new general director of the Plant was "delaying wages to the workers while buying a new Rolls-Royce and enriching himself through kickbacks from suppliers." ${ }^{93}$ Similarly, the Farm Owner revealed that the Farm on several occasions arranged for kickbacks from their suppliers when it was in need of cash. ${ }^{94}$ When talking about prevailing business practices in their industries, other interviewees confirmed that often the upper management of the private firms initiated otkat in 
relationships with state actors themselves and ultimately both sides benefited personally from any given transaction..$^{95}$

\section{State as a Promoter of the Soviet-style Personal Relations in Business}

The preservation of organizational routines from the Soviet planned economy at the state-related businesses and reliance upon otkat in enforcing contracts with them inevitably enhanced the importance of personal ties in these relations. Personal relations were directly linked to otkat; as it was put by several interviewees: "personal relations in our business mean otkat."96

The difference between personal relations with state-owned and private firms was highlighted in respect to two sales managers of the Plant, one in charge of contracts with the state-owned coalmines, and the other with large, modern private firms mostly held by oligarchs.

When the author met the "state" sales manager, he was in his early fifties with a round belly and cunning eyes. He described his style of work in the following words:

Everyone has his own style of work. I can tell a client to fuck off and in a week time we can drink vodka again, wake up in the same room or go to the sauna. I try to intermingle business ethics with friendly relations and always stay personal. ${ }^{97}$

The "private sector" sales manager was in contrast a younger, slim and sporty person in his thirties. He explained that he mostly dealt with the large private firms that worked under western corporate standards. Therefore, his style of work relied upon written correspondence with the clients. Apparently, the Head of Human Resources of the Plant had sensibly distinguished the personal traits of these managers and charged them with different groups of clients - stateowned and private firms. The difference in styles of work was so noticeable that the lawyers referred to one as the "dark past" and to another as the "bright future" of the Plant:

$\mathrm{B}$ and $\mathrm{C}$ are two sales managers with the opposite styles of work. $\mathrm{B}$ is remaining of the dark past, $\mathrm{C}$ is our bright future. $\mathrm{B}$ has to drink vodka with the middle level managers. $\mathrm{C}$ has creative mind, he works based on documents and corporate culture. These two people have different psychologies. ${ }^{98}$

Thus, a personalized type of communication and personal links retained a greater significance in the business relationships involving state-owned enterprises and this was seen as a drawback of contracting with the state.

95 Interview with the manager of the Cable Trading company, one of the Plant's buyers (October 12, 2011); interview with the Sales Manager B, the Plant (December 13, 2010); interview with the owner of the Farm (January 15, 2009).

96 Interview with the in-house Lawyer, the Plant (October 11, 2011).

97 Interview with the Sales Manager B, the Plant (September 3, 2007).

98 Interview with the Head of the Legal Department, the Plant (September 6, 2007). 


\section{Administrative Resources and State Violence in Business-to-Business Relations}

In contrast to private businesses, state agencies, Ukrainian state-owned enterprises and the "muddy" private firms were revealed in this study to be able to sometimes mobilize and use "administrative resources" (bureaucratic hierarchies and the material resources of public institutions), ${ }^{99}$ in everyday business-to-business relations.

The threat of administrative resources was invoked to pressure private firms to transact with administrative resource holders and consequently to accept unfavorable contractual terms from them. For example, the Farm was on a few occasions forced into contracting with quasi-state grain traders. In 2011, officials of the local state administration asked the Farm to sell its grain to the specified company - Hlebinvestbud. Although this trader was officially a private company, the state retained some shares, the precise amount of which was never revealed to the public. Furthermore, this small private company for unknown reasons received noticeably preferential treatment from the Yanukovych government. ${ }^{100}$ When selling grain to Hlebinvestbud, the farmers were also told to bring their grain to a specified grain elevator. When the private farmers did not rush to sell their grain to Hlebinvestbud, they got a few telephone calls from state authorities. As revealed by the Farm Owner:

Everyone has got the telephone call from the local State Administration: You know, we are also dependent people [liudi podnevolnye]; sell $\mathrm{X}$ amount of grain to Hlebinvestbud. And if I say no? You can't say no. ${ }^{101}$

Eventually, according to the Farm Owner, the farmers did what they were asked to do.

Furthermore, administrative resources in business relations can be used to pressurize the businesses to tolerate the contractual faults of the administrative resource holders and to silence claims against them. It was implicit that the claims for deficient contract performance of the latter were inadmissible. For example, when the Farm had to sell grain for the state reserve and to store it at the assigned grain elevator, this elevator unilaterally downgraded the quality of the Farm's grain. Yet, the Farm Owner deemed it pointless to involve an external laboratory to prove its rights. It was easier to be silent about the matter and never come back to this elevator unless pressured again by the administrative resources. ${ }^{102}$

Finally, administrative resources in business-to-business contracts can be used to pressure private businesses to terminate business relations with certain trading partners and thereby to restrict competition at the market. Both the Plant and the Café experienced the pressure of administrative resource in this way.

In 2010, the Plant was asked to terminate its contracts with the certain suppliers of copper, private firms that lacked an unofficial "roof" [krysha]; that is, ties to the government.

99 Allina-Pisano, "Social Contracts and Authoritarian Projects in Post-Soviet Space," 374.

100 Graham Stack, "Corruption Stains Ukraine's Oil and Grain Businesses," Business New Europe, February 2011.

101 Interview with the owner of the Farm (September 7, 2011).

102 Interview with the owner of the Farm (September 7, 2011). 
The so-called "cleansings of the market" reported by the interviewees relied upon raids of the tax inspectorate to invalidate the supply contracts with the unwanted suppliers. In November 2010, the Plant faced a tax inspection that was clearly directed against certain suppliers of its copper. As the result, the Plant terminated its business relationships with five suppliers of copper. ${ }^{103}$

Similarly, the City Council used administrative resources in an attempt to terminate the lease contract for the Owner's kiosk in 2010. Although Ukrainian law was unclear on as to whether the small businesses operating street kiosks required land permits, the Prosecutor's Office repeatedly inspected the Café, and the Department of Land Resources demanded land permits. Eventually, while the neighboring kiosks were forced to leave, the Café Owner's kiosk remained in place because she "solved everything at the upper level of Regional Land Commission" [which apparently meant bribing higher state officials].104

However, the Café Owner experienced her most painful instance of administrative resource in her fight for justice against the state-owned Leisure Park. The dispute began as a disagreement between the Owner and the Director of the Leisure Park as to the renewal of the rent contract. According to the Café Owner, the Director of the Leisure Park was unhappy about her renting land in the Park, and he wanted his daughter to have this plot instead. From the very beginning, the problems were communicated between the parties through written letters. The Park Director claimed that the Café Owner systematically left out garbage, did not properly maintain her premises, polluted the river with food remains, and did not obtain all necessary permits from the state agencies to do her business. When the level of antagonism increased, the Director of the Leisure Park switched to the strategy of inspections. He organized inspections by the tax, fire, sanitation and occupational safety inspectorates and the local Prosecutor's Office, which imposed outrageous fines on the Café. Ultimately, these inspections identified that the Café lacked a land permit. In 2007, the Prosecutor filed a lawsuit in a commercial court to evict the Café Owner.

The law on this issue, namely the Land and the Commercial Codes of Ukraine, was contradictory and unclear - one Code required businessmen to obtain permits, the other did not. This allowed the Café Owner to succeed in protecting her rights in the commercial court of the first instance, and the judge dismissed the Prosecutor's claim. The Prosecutor appealed, but this failed. In the autumn of 2007 , the Café Owner, perhaps inspired by her victory, initiated a new lawsuit against the Park to force the Director to renew the contract with her or to provide a replacement.

However, she lost this case in commercial courts in both instances, and, most importantly, in 2008 the Prosecutor brought criminal charges against her. The Café Owner suspected this was revenge for her lawsuits. A charge was fabricated that the Café Owner had illegally employed a minor in her Café. The "victim" of this alleged crime was a seventeen-year-old homeless boy who used to sleep in the park. He had two criminal convictions for robbery and was at that time in custody for an investigation of a third robbery. The Café Owner's trial took fourteen months and seven hearings. During this time, the Café Owner was not allowed to leave the town. The fees

103 Interview with the Head of the Legal Department, the Plant (December 23, 2010).

104 Interview with the owner of the Café (September 7, 2011). 
that she paid to her attorney amounted to more than UAH 10,00o. Yet, no costs could compare to emotional pain that the Café's Owner and her family suffered that year. ${ }^{105}$

The author was able to attend four hearings in this case. Most of the hearings were repeatedly deferred. When the trial actually took place, it resembled a theatre of the absurd. The young "victim" was brought to the hearing room in handcuffs and was put behind the cell while the accused was sitting with her attorney in front of the judge. The judge several times incorrectly addressed them, confusing the terms "victim" and "accused." When the Café Owner's husband testified, he ended very emotionally: "Does not everyone see that this trial is "sewn with white thread" [fabricated], that all charges are far-fetched and she is not guilty!"106

In response, the judge warned him to respect the court and threatened to expel him from the courtroom. A few other hearings took place afterwards and eventually the charges were dropped for a lack of evidence. ${ }^{107}$

The case of the Café Owner against the state-owned Leisure Park demonstrates the operation of all the stages of pressure through the administrative resources - from the threats of punitive actions to the ordered inspections by the state agencies and eventually to a criminal prosecution. It was the only case reported in this study where a criminal prosecution was initiated against a private business. Apparently, the exceptional, but real, application of this mechanism by the state presented a credible threat to all Ukrainian businesses. This case is admittedly not the only example of criminal prosecution against business people in Ukraine. However, unlike in Russia, ${ }^{108}$ there has been little research into this issue in Ukraine.

\section{State as a Big Pocket}

Notwithstanding the risks described above, average private Ukrainian businesses were competing for contracting with some state-owned enterprises and state agencies. Lucrative business opportunities outweighed the substantial deficiencies of contracting with the state. Owing to their access to state financing and their unrestricted rent-seeking opportunities, the state-owned enterprises could offer exclusive trade to their private trading partners and extremely profitable deals. For example, interviewees active on the cable market reported that a few state-owned coalmines unofficially established satellite suppliers owned by their relatives or the state officials and were served exclusively by these firms. According to the Plant's supplier:

There are small firms that serve only one state-owned enterprise, the access to which was bought by administrative resources. For example, I heard that coalmine $\mathrm{X}$ is

105 Interview with the owner of the Café (December 9, 2010).

106 Author's records of the trial in the local [raion] court of the first instance, observed December 10, 2009 .

107 Interview with the owner of the Café (December 9, 2010).

108 Gans-Morse, “Threats to Property Rights in Russia," 263; Andrei Yakovlev, Alexey Baranov, and Eugenia Nazrullaeva, “Criminal Prosecution of Business in Russia Regions: Private Interests vs 'Stick' System" (paper presented at Higher School of Economics, Moscow, 2013). 
served by the cable trading company registered by the nephew of one MP. They do not let any others in and share the profits. ${ }^{109}$

Moreover, state-owned enterprises were able to cover prices for supplies that were substantially higher than market prices. For example, the prices for coalmining cables supplied by the Plant to the state-owned coalmines exceeded production costs by ten times and remained the main source of profit for the Plant for many years.

The Café's vendors were competing among themselves to sell food supplies to state school canteens, which, in return, offered an opportunity to get rid of the unwanted goods:

We are perfectly aware that the state badly finances school canteens but we nevertheless work with them. I deliver them the goods and they pay when they can. But in return they take the goods that I need to get rid of [apparently outdated and unpopular goods].110

Finally, theFarm Owner turned out to be a co-owner of another business - a cargo transportation company. This small company managed to secure an informal agreement with the local state agency charged with road repair and became the preferred supplier of this agency. When the opportunity to receive state contracts vanished due to a change in the management of the state agency, the cargo transportation company found it very difficult to compete with others on the free market.111

Thus, despite the risks, such as the prevalence of informal practices and the increased transactional costs of contracting with the state agencies, state-owned enterprises and quasistate private firms, many private businesses voluntarily and eagerly colluded with them to collectively extract rents, ultimately at the expense of general population. As pointed out by one of the interviewees: "bad contract-enforcement is not a reason to stop to earn on the state."112

\section{Conclusions — When Risks Become Benefits}

The aim of this research was to unravel the role played by Ukrainian state in the everyday business of average Ukrainian firms through an empirical case study conducted in Eastern Ukraine in 2007-2011. During the fieldwork for this research, in 2007-2010 it was President Yushchenko and his allies in power, and in 2010 Yanukovych was elected as a President of Ukraine. Despite

109 Interview with the manager of the Cable Trading company, one of the Plant's buyers (October 12, 2011).

110 Interview with the Sales Manager of the Food Trading Company, one of the Cafés suppliers (October 28, 2011).

111 Interview with the top manager of the cargo transportation company, one of the Farm's suppliers (August 3, 2007).

112 Interview with the Sales Manager B, the Plant (December 13, 2010). 
the differences in political orientations, ${ }^{113}$ both regimes projected a similar image: the average Ukrainian businesses interviewed in this study perceived the state as complete bespredel disintegrated and scattered but unrestricted, unpredictable and violent power that relied upon administrative resources of the state to extort rent from businesses that do not belong to the inner circle of those in power. This image of the state as a predator, and small and medium businesses as victims, is corroborated by the academic literature and popular Ukrainian mass media alike. Yet, when asked to explain in greater detail about the actual business relationships with state actors, such as state agencies, state-owned enterprises and state-related private firms, the interviewees in this study revealed a mixed picture of risks and benefits.

Everyday contractual relations with the state actors were demonstrated by this study to be fraught with illegal practices, such as kickbacks from suppliers and the need to systematically violate the law on state procurement; pervasiveness of Soviet-style personal relations; risks of experiencing violent administrative pressure, including criminal prosecution; and deficiencies in the enforcement of contracts. In light of these risks, some interviewees suggested that it was safer to refrain from contracting with the state actors altogether. The move of Ukrainian businesses that lack the resources to become the part of the system towards autonomy from the system is similar to what has been observed by anthropologists, for example, in the everyday life of Moscovites. ${ }^{114}$

However, not all Ukrainian businesses chose autonomy from the system under the Yushchenko and Yanukovych regimes. Some small and medium businesses were prepared to bear the risks of contracting with the state where such cooperation offered super profits. Under such circumstances, they probably would seek to become a single preferred supplier of a stateowned enterprise or a state agency. This was a major benefit of contracting with the state.

Apart from this dubious benefit, the truly positive role of the state as a "helping hand" was identified only in one relationship. The efficient and corruption-free support to local farmers was provided by the local State Bread Inspectorate during 2007-2011. However, it is likely to have been driven by the market forces rather than by the unified state policy aimed at supporting small and medium business in Ukraine.

Thus, the empirical findings of this qualitative case study, albeit methodologically limited and in need of further confirmation, suggest that the victimization of the small and medium business in post-Soviet environment may constitute a distorted picture of reality. When researched beyond mere perceptions of the state, average Ukrainian businesses reveal no absolute moral prohibition against joining the "grabbing hand" of the state to exploit public resources and advance their own private gains, ultimately at the expense of general population. Additionally, the lack of efficient state support for the small and medium enterprises during both Yushchenko and Yanukovych governments, and after the 2014 Euromaidan Revolution due to the wartime constraints, does not offer businesses an alternative option of positive cooperation with the state. It remains doubtful whether the reforms following the 2014

113 Taras Kuzio, "From Kuchma to Yushchenko," Problems of Post-Communism 52.2 (2005); Paul D’Anieri, "What Has Changed in Ukrainian Politics? Assessing the Implications of the Orange Revolution," 5.

114 Olga Shevchenko, Crisis and the Everyday in Postsocialist Moscow (Bloomington: Indiana University Press, 2008). 
Euromaidan Revolution are capable of changing this negative pattern that has been nourished by all the previous regimes.

\section{Bibliography}

Abel, Richard L. "Law and Society: Project and Practice." Annual Review of Law and Social Science 6 (2010): $1-23$.

Akimova, Iryna, and Gerhard Schwodiauer. "The Effect of Trust in Courts on the Performance of "Ukrainian SMEs." In Trust and Entrepreneurship: A West-East Perspective, edited by H. H. Hohmann and F. Welter, 156-75. Cheltenham: Edward Elgar Publishing, 2005.

Aleksandrov, G. "Bespredel v pogonakh nepobedim?" ["Is Bespredel in Shoulder Straps Invincible?"] Argumenty i Fakty 40, 2013, 12-13.

Allina-Pisano, Jessica. "Social Contracts and Authoritarian Projects in Post-Soviet Space:The Use of Administrative Resource." Communist and Post-Communist Studies 43.4 (2010): 373-82.

Banakar, Reza, and Max Travers. Theory and Method in Socio-Legal Research. Hart, 2005.

Batjargal, Bat. "Social Capital and Entrepreneurial Performance in Russia: A Longitudinal Study." Organization Studies 24.4 (2003): 535 .

Bigsten, Arne et al. "Contract Flexibility and Dispute Resolution in African Manufacturing." Journal of Development Studies 36.4 (2000): 1-37.

Brummer, Bernhard, Stephan von Cramon-Taubadel, and Sergiy Zorya. "The Impact of Market and Policy Instability on Price Transmission between Wheat and Flour in Ukraine." European Review of Agricultural Economics 36.2 (2009): 203-30.

Cane, Peter, and Herbert Kritzer. The Oxford Handbook of Empirical Legal Research. Oxford University Press, 2010.

Cheikbossian, Guillaume. "Property Rights, Rent-Seeking and Aggregate Outcomes in Transition Economies." Economic Systems 27 (2003): 271-88.

D'Anieri, Paul. "What Has Changed in Ukrainian Politics? Assessing the Implications of the Orange Revolution." Problems of Post-Communism 52.5 (2005): 82-91.

Dubrovskiy, Vladimir, Janusz Szyrmer, and William Graves. "The Reform Driving Forces in a Rent-Seeking Society: Lessons from the Ukrainian Transition. Country Study within the Global Research Project of Understanding Reforms, the Global Development Network." CEU Policy Documentation Center (2008). Accessed May 7, 2013. http://pdc.ceu.hu/ archive/oooo6885/o1/CASE_Reform-driving-forces_2007.pdf.

Evenett, Simon, and Bernard Hoekman. "International Cooperation and the Reform of Public Procurement Policies." World Bank Policy Research Working Paper 3720 (2005). Accessed May 7, 2013. http://ssrn.com/abstract=821424.

Frye, Timothy. "Two Faces of Russian Courts: Evidence from a Survey of Company Managers." East European Constitutional Review 11.1-2 (2002): 125.

Frye, Timothy, and Ichiro Iwasaki. "Government Directors and Business-State Relations in Russia." European Journal of Political Economy 27.4 (2011): 642-58.

Gans-Morse, Jordan. "Building Property Rights: Capitalists and the Demand for Law in PostSoviet Russia." University of California, 2011. 
Gans-Morse, Jordan. "Threats to Property Rights in Russia: From Private Coercion to State Aggression." Post-Soviet Affairs 28.3 (2012): 263-95.

Gel'man, Vladimir, and Sergei Ryzhenkov. "Local Regimes, Sub-National Governance and the 'Power Vertical' in Contemporary Russia." Europe-Asia Studies 63.3 (2011): 449-65.

Gianella, Christian, and William Tompson. "Too Little Destruction, Too Little Creation: A Schumpeterian Diagnosis of Barriers to Sustained Growth in Ukraine." ECO/WKP 34 (2007).

Glikin, Maxim. Militsia i bespredel [Police and Bespredel]. Moscow: Tsentrpoligraph, 1998.

Gould, John, and Yaroslav Hetman. "Market Democracy Unleashed? Business Elites and the Crisis of Competitive Authoritarianism in Ukraine." Business and Politics 10.2 (2008): 1.

Grødeland, Åse Berit, and Aadne Aasland. "Fighting Corruption in Public Procurement in PostCommunist States: Obstacles and Solutions." Communist and Post-Communist Studies 44.1 (2011): 17-32.

Hanson, Philip, and Elizabeth Teague. "Big Business and the State in Russia." Europe-Asia Studies 57.5 (2005): 657-80.

Hellman, Joel S., Geraint Jones, and Daniel Kaufmann. "Seize the State, Seize the Day: State Capture and Influence in Transition Economies." Journal of Comparative Economics 31.4 (2003): $75^{1-73 . ~}$

Hellman, Joel, and Mark Schankerman. "Intervention, Corruption and Capture: The Nexus between Enterprises and the State." Economics of Transition 8.3 (2000): 545-76.

Hendley, Kathryn. "Enforcing Judgments in Russian Economic Courts." Post-Soviet Affairs 20.1 (2004): 46-82.

Hendley, Kathryn. "Mobilizing Law in Contemporary Russia: The Evolution of Disputes over Home Repair Projects." The American Journal of Comparative Law 58.3 (2010): 631-78.

Hendley, Kathryn. "Resolving Problems among Neighbors in Post-Soviet Russia: Uncovering the Norms of the Pod'ezd." Law \& Social Inquiry 36.2 (2011): 388-418.

Hendley, Kathryn. “Telephone Law' and the 'Rule of Law': The Russian Case." Hague Journal on the Rule of Law 1.2 (2009): 241-62.

Hendley, Kathryn, Peter Murrell, and Randi Ryterman. "Law, Relationships and Private Enforcement: Transactional Strategies of Russian Enterprises." Europe-Asia Studies $5^{2.4}$ (2000): 627-56.

Hoskisson, Robert, Lorraine Eden, Chung Ming Lau, and Mike Wright. "Strategy in Emerging Economies." Academy of Management Journal (2000): 249-67.

IFC. "Ukraine Commercial Dispute Resolution Study: Researching Commercial Disputes among Ukrainian Companies.” International Finance Corporation World Bank Group, 2007.

Iwasaki, Ichiro, and Taku Suzuki. "Transition Strategy, Corporate Exploitation, and State Capture: An Empirical Analysis of the Former Soviet States." Communist and Post-Communist Studies 40.4 (2007): 393-422.

Jensen, Nathan. "Economic Reform, State Capture, and International Investment in Transition Economies." Journal of International Development 14.7 (2002): 973-77. 
Johnson, Simon, John McMillan, and Christopher Woodruff. "Entrepreneurs and the Ordering of Institutional Reform: Poland, Slovakia, Romania, Russia and Ukraine Compared." Economics of Transition 8.1 (2000): $1-36$.

Kartsev, Vladimir. Zhirinovsky: An Insider's Account of Yeltsin's Chief Rival and Bespredel-the New Russian Roulette. New York: Columbia University Press, 2013.

Kondratyeva, Olga. "Vykonannia sudovykh rishen: Novi zakony ta problemy." ["Enforcement of Court Judgments: New Laws and Problems."] Iurydychnyi visnyk Ukrayiny, February 2-8, 2013.

Kubicek, Paul. "Problems of Post-Post-Communism: Ukraine after the Orange Revolution." Democratization 16.2 (2009): 323-43.

Kudelia, Serhiy. "The Sources of Continuity and Change of Ukraine's Incomplete State." Communist and Post-Communist Studies 45·3-4 (2012): 417-28.

Kurkchiyan, Marina. "The Impact of the Transition on the Role of Law in Russia." In Explorations in Legal Cultures, edited by F. Bruinsma and D. Nelken, 75-111. Reed Business BV, 2007.

Kurkchiyan, Marina. "Justice through Bureaucracy: The Ukrainian Model." Social \& Legal Studies 22.4 (2013): 515-33.

Kurkchiyan, Marina. "Russian Legal Culture: An Analysis of Adaptive Response to an Institutional Transplant." Law and Social Inquiry 34.2 (2009): 337-64.

Kurkchiyan, Marina. "What to Expect from Institutional Transplants? An Experience of Setting up Media Self-Regulation in Russia and Bosnia." International Journal of Law in Context $8.1(2012): 115-31$.

Kuzio, Taras. "Crime, Politics and Business in 1990 os Ukraine." Communist and Post-Communist Studies 47.2 (2014): 195-210.

Kuzio, Taras. "From Kuchma to Yushchenko." Problems of Post-Communism 52.2 (2005): 29-44.

Kyselova, Tatiana. "Comparing Contracts through a Socio-Legal Approach: Case Study of Ukraine." Journal of Comparative Law 8.1 (2013): 146-71.

Kyselova, Tatiana. "Contract Enforcement in Post-Soviet Ukrainian Business." University of Oxford, 2012.

Kyselova, Tatiana. "Dualism of Ukrainian Commercial Courts: Exploratory Study." Hague Journal on the Rule of Law 6.2 (2014): 178-201.

Kyselova, Tatiana. "Legal Transformations of Business Disputes in Post-Soviet Ukraine." Oñati Socio-Legal Series 1.6 (2011).

Kyselova, Tatiana. "Pretenziia Dispute Resolution in Ukraine: Formal and Informal Transformation." Review of Central and East European Law 40.1 (2015): 1-35.

Ledyaev, Valeri. "Domination, Power and Authority in Russia: Basic Characteristics and Forms." Journal of Communist Studies and Transition Politics 24.1 (2008): 17-36.

Macaulay, Stewart. "Non-Contractual Relations in Business: A Preliminary Study." American Sociological Review 28.1 (1963): 55-67.

Markus, Stanislav. "Secure Property as a Bottom-up Process: Firms, Stakeholders, and Predators in Weak States." World Politics 64.2 (2012): 242-77.

McFaul, Michael. "State Power, Institutional Change, and the Politics of Privatization in Russia." World Politics 47 (1995): 210-43. 
Monaghan, Andrew. "The Vertikal: Power and Authority in Russia." International Affairs 88.1 (2012): 1-16.

Nikitinskii, Leonid. "Bespredel." ["Bespredel."] Ogoniok, August 6-13, 1988, 27-29.

Oleinik, Anton. "A Distrustful Economy: An Inquiry into Foundations of the Russian Market." Journal of Economic Issues 39.1 (2005): 53-75.

Rojansky, Matthew. "Corporate Raiding in Ukraine: Prevention, Defense, and Policy Reform." Review of Central and East European Law 39.3-4 (2014): 245-89.

Rozhnov, Konstantin. "Russia's Bid to Stop Kickbacks Worth \$33bn a Year." Business Reporter BBC News, November 5, 2010.

Shevchenko, Olga. Crisis and the Everyday in Postsocialist Moscow. Bloomington: Indiana University Press, 2008.

Shleifer, Andrei, and Robert Vishny. The Grabbing Hand: Government Pathologies and Their Cures. Cambridge, MA: Harvard University Press, 1998.

Slinko, Irina, Evgeny Yakovlev, and Ekaterina Zhuravskaya. "Laws for Sale: Evidence from Russia." American Law and Economics Review 7.1 (2005): 284-318.

Smallbone, David, and Friederike Welter. "The Role of Government in Sme Development in Transition Economies." International Small Business Journal 19.4 (2001): 63-77.

Stack, Graham. "Corruption Stains Ukraine's Oil and Grain Businesses." Business New Europe February 2011.

Stephenson, Svetlana. "The Kazan Leviathan: Russian Street Gangs as Agents of Social Order." The Sociological Review 59.2 (2011): 324-47.

Stewart, Susan. "Public Procurement Reform in Ukraine:The Implications of Neopatrimonialism for External Actors." Demokratizatsiya 21.2 (2013): 197-214.

Treviño, A. Javier. "The Sociology of Law in Global Perspective." The American Sociologist 32.2 (2001): 5-9.

Usheva, Marina. “Ob Ocherednoi Atake Na Moratorii." ["AnotherCampaign against Moratorium."] Yurydychna Praktyka 18 (2007).

Vinogradova, Elena. "The Big Issue of Small Businesses: Contract Enforcement in the New Russia." University of Maryland, 2005.

Volkov, Vadim. "Hostile Enterprise Takeovers: Russian Economy in 1998-2002." Review of Central and East European Law 29.4 (2004): 527-48.

Volkov, Vadim. "Violent Entrepreneurship in Post-Communist Russia." Europe-Asia Studies 51.5 (1999): 741-54.

Yakovlev, Andrei. "The Evolution of Business — State Interaction in Russia: From State Capture to Business Capture?" Europe-Asia Studies 58.7 (2006): 1033-56.

Yakovlev, Andrei, Alexey Baranov, and Eugenia Nazrullaeva. "Criminal Prosecution of Business in Russia Regions: Private Interests Vs 'Stick' System.' Working paper, Higher School of Economics, Moscow (2013). 
Tatiana Kyselova is a Marie Curie/COFUND postdoctoral fellow at University of Turin, Italy and a visiting teaching fellow at Queen Mary, University of London. In 2012-2015 she worked as an Associate Professor in the Law Faculty of the Kyiv-Mohyla Academy in Kyiv, Ukraine. She received her LLM from the London School of Economics and Political Science, kandidat nauk from the Ukrainian National Academy of Science and a DPhil from University of Oxford. She specializes in socio-legal studies, alternative dispute resolution, access to justice, and postSoviet transition.

Appendix 1

TABLE 1. SUMMARY OF BACKGROUND INFORMATION ON THE RESEARCHED Firms

\begin{tabular}{|c|c|c|c|}
\hline & The Plant & The Farm & The Café \\
\hline $\begin{array}{l}\text { Size (number of } \\
\text { employees) in } 2007\end{array}$ & $55^{2}$ & $5^{8}$ & 5 \\
\hline $\begin{array}{l}\text { Sectors of the } \\
\text { economy }\end{array}$ & $\begin{array}{l}\text { Industrial } \\
\text { manufacturing }\end{array}$ & Agriculture & $\begin{array}{l}\text { Retail trade and } \\
\text { restaurant service }\end{array}$ \\
\hline $\begin{array}{l}\text { Geographic area of } \\
\text { the customer base }{ }^{1}\end{array}$ & $\begin{array}{l}\text { Ukraine and former } \\
\text { Soviet Union }\end{array}$ & $\begin{array}{l}\text { Region (Oblast) of } \\
\text { Ukraine }\end{array}$ & One city district \\
\hline Founded & 1962 & 2000 & 1995 \\
\hline Corporate structure & $\begin{array}{l}\text { Closed joint-stock } \\
\text { company }\end{array}$ & $\begin{array}{l}\text { Limited-liability } \\
\text { company }\end{array}$ & Sole proprietorship \\
\hline $\begin{array}{l}\text { Annual turnover } \\
\text { (UAH) }\end{array}$ & $240,000,000$ & 1,০০০,০০০ & 80,000 \\
\hline
\end{tabular}

Number of buyers

and suppliers in

\begin{tabular}{|c|c|c|c|}
\hline 2007 & 500 & 122 & 24 \\
\hline $\begin{array}{l}\text { Lawyers or legally } \\
\text { trained personnel }\end{array}$ & $\begin{array}{l}\text { Two-person Legal } \\
\text { Department. One of } \\
\text { the two CEOs also } \\
\text { has a law degree }\end{array}$ & $\begin{array}{l}\text { The owner has a law } \\
\text { degree }\end{array}$ & $\begin{array}{l}\text { The owner has } \\
\text { experience of self- } \\
\text { representation in the } \\
\text { commercial courts }\end{array}$ \\
\hline
\end{tabular}

115 For the sake of confidentiality the precise geographic location of the firms is not revealed. 